\title{
En kvinne i 60-årene med store trombemasser i aorta
}

\author{
En kvinne i 60-årene ble innlagt med akutte smerter og kraftsvikt i begge \\ beina. Klinisk undersøkelse viste alvorlig iskemi i underekstremitetene. \\ CT-angiografi avslørte massive trombemasser i abdominalaorta, og det \\ ble gjort akutt trombektomi. Den videre utredning avdekket en uvanlig \\ årsak til trombosedanningen.
}

En kvinne i 60-årene, med kjent seropositiv revmatoid artritt og tre tidligere innleggelser for akutt pankreatitt, ble innlagt med magesmerter. Amylase ved innleggelsen var $1611 \mathrm{U} / \mathrm{l} /<120 \mathrm{U} / \mathrm{ll}$ og CT abdomen viste forandringer forenlig med akutt pankreatitt. Hun ble raskt bedre etter intravenøs væskebehandling og utskrevet etter fem dager.

13 dager etter utskrivningen ble hun innlagt i nevrologisk avdeling med spørsmål om transitorisk iskemisk anfall (TIA) etter to dager med episodevis svimmelhet og snøvlete tale. Hun anga også lette smerter $i$ høyre flanke som ikke liknet pankreatittsmertene. Nevrologisk undersøkelse var negativ. CT caput og ultralyd av halskar var normale.

12 år tidligere hadde hun hatt et lite hjerneinfarkt og hadde siden brukt klopidogrel. Blodprøver tatt ved innkomst avslørte en nyoppstått trombocytopeni. Trombocyttene hadde falt fra $315 \cdot 10^{9} / \mathrm{l}$ ved utskrivningen 13 dager tidligere til $69 \cdot 10^{9} / \mathrm{l}\left(145-390 \cdot 10^{9} / \mathrm{l}\right)$. Samtidig hadde hun en lett forlenget aktivert partiell tromboplastintid (APTT) på 50 sekunder (< 42 sek), men normal INR på 1,0 $(\leq 1,1)$. Hun hadde ingen flere episoder med svimmelhet eller talevansker under innleggelsen, og ble utskrevet etter ett døgn uten at man hadde funnet årsaken til symptomene.

Ervervet trombocytopeni kan skyldes produksjonssvikt eller perifer destruksjon/økt forbruk. Produksjonssvikten kan være benign (medikamenter, vitamin $\mathrm{B}_{12} /$ folatmangel, cytostatika, stråleskade eller infeksjoner) eller malign (hematologisk neoplasi eller beinmargsmetastaser).

Perifer destruksjon eller økt forbruk er enten immunologisk betinget (f.eks. immunologisk trombocytopeni, heparinindusert trombocytopeni og posttransfusjonspurpura) eller ikke-immunologisk betinget (disseminert intravaskulær koagulasjon (DIC), trombotisk trombocytopenisk purpura (TTP), HELLP-syndrom (hemolyse, økte serumnivåer av leverenzymer og trombocytopeni), hypersplenisme og infeksjoner). Pseudo- trombocytopeni bør også utelukkes ved å se etter trombocyttaggregater i blodutstryk (1).

Bare noen timer etter utskrivningen ble hun reinnlagt med akutte smerter og sviktende kraft $i$ underekstremitetene. Ved klinisk undersøkelse hadde hun bleke føtter og manglende lyskepuls bilateralt. Det var ikke målbart trykk ved dopplerundersøkelse av underekstremitetene. Etter hvert fikk hun blålig misfarging av tærne på høyre fot, forenlig med kritisk iskemi. CT angiografi av abdomen/bekken og underekstremiteter viste massive trombemasser omkring aortabifurkaturen (fig 1).

Hun ble overflyttet til karkirurgisk seksjon, og et halvt døgn etter innleggelsen ble det utført åpen trombektomi av distale aorta, bekken- og lårarterier - med godt resultat. Det ble bemerket at trombemassene virket organiserte og at det var påfallende lite arteriosklerose i karveggene. Under inngrepet ble det etter standard prosedyre skylt med rikelig heparinisert saltvann i de trombektomerte karene.

Akutt trombosering i aorta er en alvorlig tilstand som oftest skyldes embolisering fra en sentral kilde, vanligvis hjertet. Trombose med underliggende uttalt arteriosklerose er nest vanligste årsak (2).

Sadelembolus i aortabifurkaturen uten lokale veggforandringer ga mistanke om sentral embolikilde eller systemisk årsak. Verken CT-angiografi av torakalaorta eller ekkokardiografi avdekket noen embolikilde.

Postoperativt fikk pasienten lavmolekylært heparin subkutant (dalteparin, Fragmin 5000 IE $\times 2$ ). To dager senere falt trombocyttene til $24 \cdot 10^{9} / \mathrm{l}$. Tredje postoperative dag falt de ytterligere, til $15 \cdot 10^{\%} /$ l. Hematolog ble kontaktet for utredning av tromboseårsak og trombocytopeni.

Pasienten utviklet arterielle tromboser og uttalt trombocytopeni uten blødningstendens. Mulige differensialdiagnoser er disseminert
Helle Borgstrøm Hager helle.hager@siv.no Sentrallaboratoriet

Emil Nyquist

Hematologisk seksjon

Russell Allen Jacobsen Karkirurgisk seksjon

Anders Mikael Hager Radiologisk avdeling

Sykehuset i Vestfold

Engelsk oversettelse på www.tidsskriftet.no 


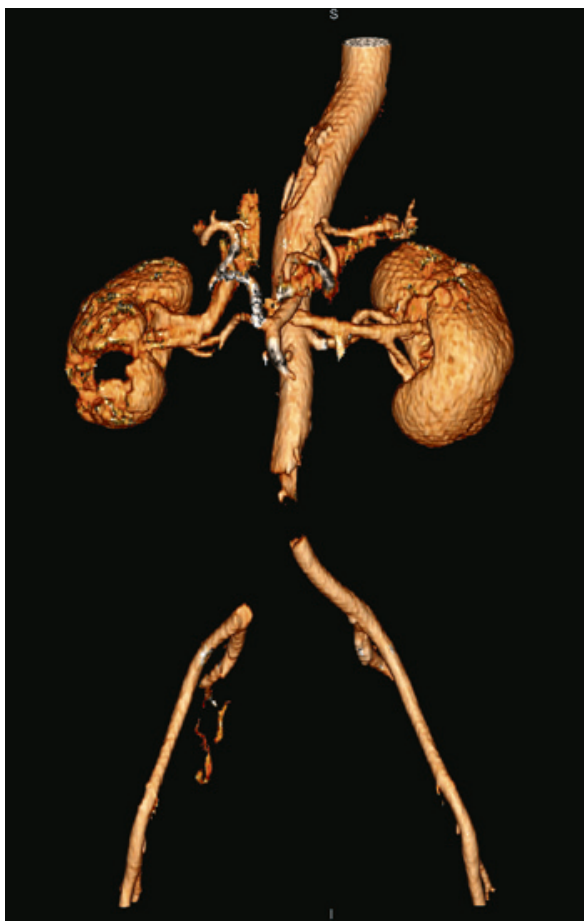

Figur 1 Tredimensjonal CT-angiografi viser manglende kontrastfylling i distale abdominalaorta og høyre a. iliaca communis, forenlig med okkluderende trombemasser. I tillegg ses fokal perfusjonsdefekt kaudalt i høyre nyre, noe som gir mistanke om infarkt

intravaskulær koagulasjon, trombotisk trombocytopenisk purpura, katastrofisk antifosfolipidsyndrom og heparinindusert trombocytopeni (HIT). Hematolog bestilte blodprøver (tab 1, 4. kolonne) og et blodutstryk (fig 2). Basert på disse resultatene ble trombotisk trombocytopenisk purpura mistenkt som årsak til trombocytopeni og tromboser.

Klopidogrel kan i sjeldne tilfeller medføre trombotisk trombocytopenisk purpura og ble derfor seponert (3). Både trombocytopeni, schistocytter, høy laktatdehydrogenase, økte retikulocytter, negativ direkte antiglobulintest og normale koagulasjonsprøver kunne passe med trombotisk trombocytopenisk purpura. Ved denne tilstanden er det imidlertid vanligst med tromboser i mikrosirkulasjonen, ikke i de store arteriene. Dessuten er haptoglobinnivået nedsatt $\mathrm{og}$ bilirubinnivået oftest økt (4).

Ved disseminert intravaskulær koagulasjon ser man økt koagulering og fibrinolyse med både tromboseutvikling og blødningstendens. APTT og INR er som regel økt og fibrinogennivået er vanligvis lavt, men variasjonen er stor. Disseminert intravaskulær koagulasjon er alltid assosiert med annen alvorlig grunnsykdom, for eksempel sepsis. Den kliniske tilstanden ga imidlertid ikke mistanke om sepsis, og hun hadde ingen blødningstendens.

Katastrofisk antifosfolipidsyndrom kan ses sekundært til annen autoimmun sykdom og kan medføre både trombocytopeni og arterielle tromboser. Tilstanden gir vanligvis forlenget APTT ved tilstedeværelse av lupusantikoagulant og lett eller ingen trombocytopeni. En tredel har schistocytter i blodet (5). Med normal lupusantikoagulant, kardiolipinantistoffer og anti- $\beta 2$-glykoprotein I-antistoffer var diagnosen mindre sannsynlig.
Heparinindusert trombocytopeni ble også vurdert som en mulig differensialdiagnose. Dette er en immunologisk komplikasjon med trombocytopeni forårsaket av antistoffmediert plateaktivering og økt trombosetendens. Tilstanden opptrer oftest 5-14 dager etter start av eksponering for ufraksjonert (UFH) eller lavmolekylært heparin (LMH) (6).

Heparinindusert trombocytopeni ble vurdert som lite sannsynlig fordi det ifølge medikamentkurvene ikke var gitt heparin under de to første innleggelsene. Fordi man ikke helt kunne utelukke muligheten for denne tilstanden, ble dalteparin erstattet av fondaparinuks (Arixtra). Fondaparinuks er en syntetisk, selektiv hemmer av aktivert faktor X (Xa) som forsøksvis har vært brukt til behandling av heparinindusert trombocytopeni (7).

Trombotisk trombocytopenisk purpura ble ansett som den mest sannsynlige diagnosen. Behandlingen er plasmautskifting. Slik behandling kom i gang to dager senere, men trombocyttene begynte likevel å stige før det (fig 3).

Under plasmautskifting opplevde man problemer med koagulering i dialysefilteret og besluttet derfor etter to dager å bytte ut fondaparinuks med heparin. Samtidig ble dalteparin gjeninnsatt som trombosemedikament. I de påfølgende dagene falt trombocyttene til tross for plasmautskifting. Nefrolog og hematolog ble da enige om at man likevel måtte mistenke heparinindusert trombocytopeni.

Plasmautskiftingen ble avsluttet, og dal-

Tabell 1 Blodprøvesvar

\begin{tabular}{|c|c|c|c|c|c|}
\hline & $\begin{array}{l}\text { Første innleggelse, } \\
\text { akutt pankreatitt, } \\
\text { utskrivningsdagen }\end{array}$ & $\begin{array}{l}\text { Andre innleggelse, } \\
\text { TIA? } 13 \text { dager senere }\end{array}$ & $\begin{array}{l}\text { Tredje innleggelse, } \\
\text { neste dag med } \\
\text { alvorlig iskemi }\end{array}$ & $\begin{array}{l}\text { Fjerde post- } \\
\text { operative dag }\end{array}$ & Referanseverdier \\
\hline B-hemoglobin (g/100 ml) & 13,0 & 13,2 & 12,6 & 8,7 & $11,7-15,3$ \\
\hline B-leukocytter $\left(\cdot 10^{9} / \mathrm{l}\right)$ & 5,7 & 11,4 & 16,3 & 10,4 & $3,50-10,0$ \\
\hline B-trombocytter $\left(\cdot 10^{9} / l\right)$ & 315 & 69 & 77 & 21 & $145-390$ \\
\hline B-retikulocytter $\left(\cdot 10^{9} / \mathrm{l}\right)$ & & 124 & 115 & 184 & $30-100$ \\
\hline P-kreatinin $(\mu \mathrm{mol} / \mathrm{l})$ & 67 & 77 & 67 & 67 & $45-90$ \\
\hline P-LD (U/L) & - & - & - & 631 & $105-205$ \\
\hline P-haptoglobin (g/l) & - & - & - & 1,43 & $0,50-2,10$ \\
\hline P-APTT (sek) & - & 50 & 52 & 41 & $<42$ \\
\hline P-INR & - & 1,0 & 1,1 & 1,1 & $\leq 1,1$ \\
\hline P-fibrinogen $(g / l)$ & - & - & - & 4,5 & $2,0-4,5$ \\
\hline B-direkte antiglobulin-test & - & - & - & Negativ & Negativ \\
\hline P-bilirubin, total (U/l) & 8 & - & 20 & 10 & $<25$ \\
\hline
\end{tabular}


teparin erstattet med fondaparinuks. Det ble også bestilt heparinindusert antistoff-test (ID-PaGIA Heparin/PF4 antibody test fra Biorad). Den var sterkt positiv og bekreftet at pasienten hadde IgG-antistoffer mot platefaktor 4-heparin.

Men det viktigste spørsmålet var fortsatt ubesvart: Hadde hun fått heparin under de to første innleggelsene?

Ifølge medikamentkurvene hadde hun verken fått lavmolylært eller ufraksjonert heparin. Hun hadde imidlertid fătt væske intravenøst under innleggelsene. I prosedyren for innlegging, stell og observasjon av perifere venekatetre ved vårt sykehus var det anbefalt skylling med heparin $100 \mathrm{IE} / \mathrm{ml}$ dersom venekateteret ikke var i kontinuerlig bruk. Pasienten hadde derfor fått små doser ufraksjonert heparin flere ganger i døgnet.

Det er publisert flere artikler om pasienter som har fått heparinindusert trombocytopeni etter at de ikke har fått annet heparin enn det som gis ved skylling av sentrale venekatetre $(8,9)$ eller arteriekraner $(10)$.

Da diagnosen heparinindusert trombocytopeni ble bekreftet, ble dalteparin seponert og man fortsatte antikoagualasjonsbehandlingen med fondaparinuks. Det ble notert heparinallergi i elektronisk journal under kritiske opplysninger, men ikke på medikamentkurven. Melding om alvorlig medikamentbivirkning ble sendt til Regionalt legemiddelinformasjonssenter (RELIS), som senere bekreftet årsakssammenhengen mellom heparin/ dalteparin og diagnosen.

Pasienten ble utskrevet med warfarinbehandling og med god sirkulasjon i begge bein. Ved kontroll åtte uker senere var hun i god allmenntilstand og hadde normal ankelarm-indeks.

\section{Diskusjon}

Ved heparinindusert trombocytopeni dannes autoantistoffer som bindes til komplekser av platefaktor 4 (PF4) bundet til heparin. Immunkomplekser som inneholder IgG-antistoffer og PF4-heparin-komplekser binder seg til Fc-reseptorer på blodplatenes overflate. Dette fører til økt utskilling av platefaktor 4, noe som igjen medfører danning av flere immunkomplekser, økt plateaktivering og utskilling av mikropartikler fra platene. Immunkompleksene binder seg til endoteloverflaten og utløser en kaskade som resulterer i plateaggregering og trombosedanning. Trombocyttene forbrukes i prosessen og faller typisk mer enn $50 \%$ fra utgangspunktet. Halvparten av pasientene utvikler i tillegg tromboser. Disse er vanligvis venøse - arterielle tromboser rammer oftest de store arteriene i underekstremitetene, sjeldnere cerebrale kar og hjertets arterier (11).

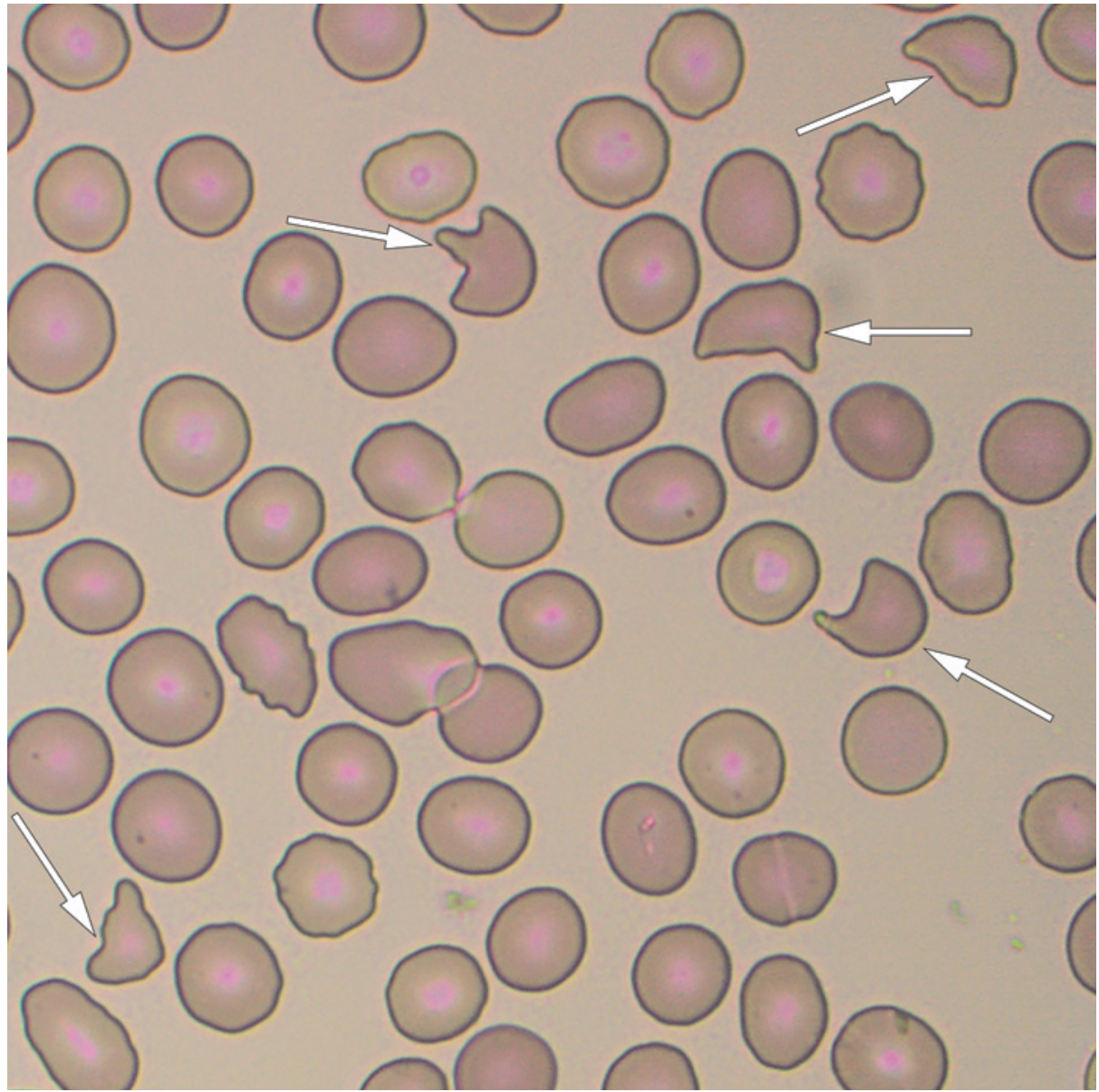

Figur 2 Blodutstryk med schistocytter (piler)

Trombocytter $\left(10^{\circ} / \mathrm{l}\right.$

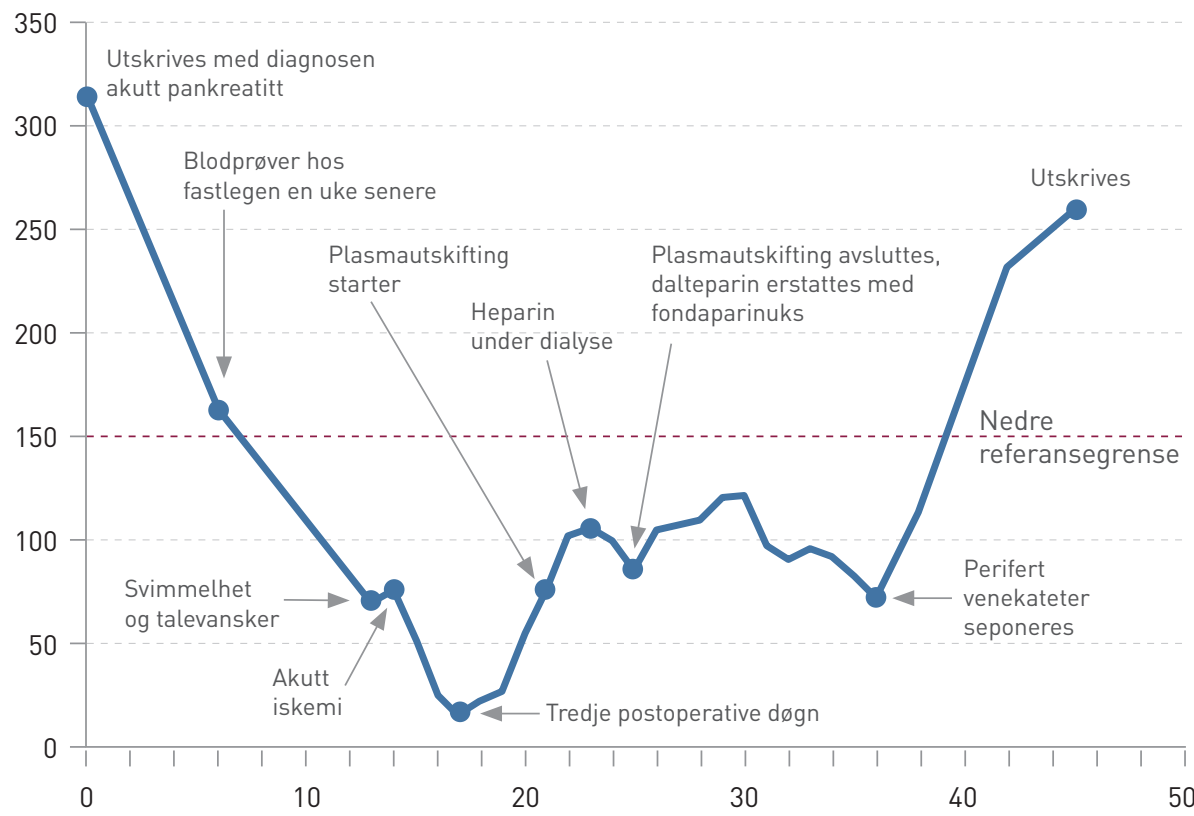

Dager etter innleggelse

Figur 3 Trombocyttverdier fra første utskrivning (dag 0) og frem til pasienten utskrives for tredje gang 45 dager senere 
Tabell 24 T-skår til estimering av pretestsannsynlighet for heparinindusert trombocytopeni. Etter Warkentin \& Heddle (15)

\begin{tabular}{|c|c|c|c|}
\hline Kategori & 2 poeng & 1 poeng & 0 poeng \\
\hline Trombocytopeni & $\begin{array}{l}>50 \% \text { trombocyttfall eller nadir } \\
20-100 \cdot 10^{9} / \mathrm{l}\end{array}$ & $\begin{array}{l}30-50 \% \text { trombocyttfall eller nadir } \\
10-19 \cdot 10^{9} / \mathrm{l}\end{array}$ & $\begin{array}{l}<30 \% \text { trombocyttfall eller nadir } \\
<10 \cdot 10 \% / l\end{array}$ \\
\hline $\begin{array}{l}\text { Tidspunkt for fall } \\
\text { av trombocytter }\end{array}$ & $\begin{array}{l}\text { Dag } 5-10 \text { eller }<1 \text { dag dersom } \\
\text { heparinbehandling de siste } \\
100 \text { dager }\end{array}$ & $\begin{array}{l}\text { > Dag } 10 \text { eller usikkert (f.eks. ikke målt } \\
\text { før senere, men passer med heparin- } \\
\text { indusert trombocytopenil }\end{array}$ & $\begin{array}{l}\text { Trombocyttfallet kommer før } \\
\text { dag } 4 \text { log ingen nylig heparin- } \\
\text { behandling) }\end{array}$ \\
\hline $\begin{array}{l}\text { Trombose eller andre } \\
\text { sekveler }\end{array}$ & $\begin{array}{l}\text { Påvist trombose(r), hudnekrose } \\
\text { eller anafylaksi etter intravenøs } \\
\text { heparin }\end{array}$ & $\begin{array}{l}\text { Progredierende/tilbakevendende trombo- } \\
\text { ser, ikke nekrotisk hudlesjon eller mistenkt, } \\
\text { men ikke verifisert trombose }\end{array}$ & $\begin{array}{l}\text { Ingen tromboser eller andre } \\
\text { suspekte symptomer }\end{array}$ \\
\hline $\begin{array}{l}\text { Trombocytopeni av annen } \\
\text { årsak }\end{array}$ & Ingen andre sannsynlige årsaker & Annen årsak mulig & Annen årsak sannsynlig \\
\hline
\end{tabular}

Heparinindusert trombocytopeni rammer $0,2-5,0 \%$ av dem som får heparin i mer enn fire dager (6). Vanligvis oppstår tilstanden mens heparinbehandlingen fortsatt pågår, men den kan i sjeldne tilfeller opptre senere i forløpet - opptil flere uker etter at heparinbehandlingen er avsluttet - kalt «delayedonset HIT» (6). En sent opptredende heparinindusert trombocytopeni kan forklare hvorfor trombocyttene hos denne pasienten ble halvert en uke etter første utskrivning (fig 3) og falt ytterligere de påfølgende dager samtidig som hun utviklet arterielle tromboser i aorta og bekkenarterier. Symptomene som ble oppfattet som transitorisk iskemisk anfall, kan også ha vært assosiert med heparinindusert trombocytopeni, med forbigående plateaggregering i cerebrale kar (12).

Hos $30 \%$ av pasienter med heparinindusert trombocytopeni kan tilstanden utvikles i løpet av 24 timer etter heparineksponering. Denne formen rammer dem som har fått heparin i løpet av de siste tre måneder og allerede har dannet autoantistoffer (11). Heparinindusert trombocytopeni er opptil ti ganger så hyppig hos pasienter som får ufraksjonert heparin som hos dem som får lavmolekylært (13). I en studie med ortopediske pasienter fikk $5 \%$ heparinindusert trombocytopeni etter ufraksjonert heparin som tromboseprofylakse, men bare $0,9 \%$ etter lavmolekylært heparin (14). Kirurgiske pasienter rammes oftere enn medisinske, kvinner oftere enn menn og terapeutiske heparindoser gir høyere risiko for heparinindusert trombocytopeni enn profylaktiske doser.

Trombose og trombocytopeni kan ha mange andre årsaker enn heparinbehandling, og det er anbefalt å bruke et skåringssystem for å vurdere sannsynligheten for heparinindusert trombocytopeni før man bestiller en antistofftest. Best validert er den såkalte $4 \mathrm{~T}$ skår ( $\operatorname{tab} 2$ ), som estimerer sannsynligheten for tilstanden basert på trombocyttverdi, tidspunkt for debut, forekomst av eventuelle tromboser og sannsynligheten for andre dia- gnoser (15). Ved lav poengsum (0-3 poeng) kan tilstanden utelukkes med høy sannsynlighet, mens ved intermediær (4-5 poeng) eller høy poengsum (6-8 poeng) skal heparin seponeres og erstattes av en direkte trombinhemmer (16). Vår pasient fikk en poengsum på 6-7 poeng, det vil si høy sannsynlighet for heparinindusert trombocytopeni.

En høy 4 T-skår bør bekreftes med påvisning av antistoffer mot PF4-heparin-komplekser. Funksjonelle tester der man tilsetter pasientens serum og heparin til blodplater tappet fra blodgivere og påviser eventuell plateaggregering, utføres foreløpig ikke i Norge. Flere laboratorier gjør derimot immunologiske tester. Immunologiske tester for heparinindusert trombocytopeni har en sensitivitet på nær $100 \%$, men varierende spesifisitet (40-80\%) (17). En positiv test betyr ikke at antistoffene er klinisk relevante, de trenger ikke medføre plateaggregering og trombosedanning in vivo. En negativ test er derimot godt egnet til å utelukke heparinindusert trombocytopeni.

Blodutstryk fra pasienten viste flere schistocytter. Dette er uvanlig ved heparinindusert trombocytopeni (18), men vanlig ved disseminert intravaskulær koagulasjon (19). Warkentin og medarbeidere undersøkte 12 pasienter med sent opptredende heparinindusert trombocytopeni og fant at tre av dem også hadde disseminert intravaskulær koagulasjon. Dette er en sjelden komplikasjon til heparinindusert trombocytopeni, men trolig vanligere ved denne sene formen (20). Ved andre innleggelse av pasienten ble det påvist en lett forlenget aktivert partiell tromboplastintid på 50 sekunder, som senere i forløpet ble normalisert. Den forlengede tromboplastintiden og schistocyttene kan altså ha vært uttrykk for lavgradig disseminert intravaskulær koagulasjon.

Vanligvis øker trombocyttene til over nedre referansegrense $\mathrm{i}$ løpet av fire dager etter seponering av heparin, men det kan ta opptil to uker hos pasienter med svært høye antistofftitre (6). Hos vår pasient tok det nesten fire uker før trombocyttene ble normalisert. Trombocyttallet falt seks dager etter at heparin og dalteparin ble seponert (fig 3, dag 31). Trolig skyldes dette fallet at man fortsatte å skylle det perifere venekateteret med heparin, sannsynligvis fordi dette var en innarbeidet prosedyre og det ikke var spesifisert på medikamentkurven at heparinskylling måtte unngås. Først da den intravenøse behandlingen ble avsluttet og pasienten ikke lenger hadde behov for perifert venekateter, begynte trombocyttene å stige igjen.

Britiske retningslinjer anbefaler at trombocyttallet kontrolleres før, under og etter avsluttet heparineksponering, spesielt ved mer enn fire dagers bruk og hos kirurgiske pasienter, og særlig hvis de har fătt ufraksjonert heparin (16). Siden tilstanden kan opptre flere dager etter at heparineksponeringen er avsluttet, er det viktig at også leger i primærhelsetjenesten har kunnskap om tilstanden. Ved tidlig mistanke om heparinindusert trombocytopeni og måling av trombocytter kan komplikasjonene begrenses og behandles. Uten behandling har tilstanden høy morbiditet og mortalitet (11).

Hendelsen ble meldt $i$ vårt avvikssystem som en uønsket pasienthendelse og behandlet i kvalitetsrådet. Prosedyren med skylling av perifere venekatetre med heparin er nå endret ved vårt sykehus. Skylling med saltvann har vist seg å være like bra som skylling med heparin (21), samtidig som man unngår de alvorlige heparininduserte bivirkningene. De fleste andre sykehus i landet bruker kun saltvann til skylling av perifere venekatetre.

I en Cochrane-rapport fra 2014 ble det konkludert med at skylling av sentrale venøse katetre med saltvann ikke gir større risiko for infeksjoner eller at de går tette sammenliknet med heparinskylling (22). En nasjonal fagprosedyre under Kunnskapssenteret anbefaler at sentrale venøse katetre som er i daglig 
bruk kun skylles med saltvann (23). Dersom kateteret ikke er i daglig bruk, anbefales ukentlig skylling med saltvann og at kateteret låses med heparin $100 \mathrm{IE} / \mathrm{ml}$. Heparinskylling medfører en liten, men økt risiko for utvikling av heparinindusert trombocytopeni. Kanskje bør heparinskylling/heparinlås anføres på medikamentkurvene for å minne oss på dette?

Pasienten har gitt samtykke til at artikkelen blir publisert.

\section{Helle Borgstrøm Hager (f. 1969)}

er spesialist i medisinsk biokjemi og avdelingsoverlege.

Forfatter har fylt ut ICMJE-skjemaet og oppgir ingen interessekonflikter.

\section{Emil Nyquist (f. 1972)}

er spesialist i blodsykdommer, seksjonsoverlege og nettredaktør i Norsk selskap for hematologi.

Forfatter har fylt ut ICMJE-skjemaet og oppgir ingen interessekonflikter.

\section{Russell Allen Jacobsen (f. 1963)}

er spesialist i karkirurgi og overlege.

Forfatter har fylt ut ICMJE-skjemaet og oppgir ingen interessekonflikter.

\section{Anders Mikael Hager (f. 1969)}

er spesialist i radiologi og avdelingsoverlege. Forfatter har fylt ut ICMJE-skjemaet og oppgir ingen interessekonflikter.

\section{Litteratur}

1. Hagve TA, Berg JP. red. Klinisk biokjemi og fysiologi. 5. utg. Oslo: Gyldendal, 2015.

2. Buth J, Cuypers $P$. The diagnosis and treatment of acute aortic occlusions. J Mal Vasc 1996; 21: $133-5$

3. Nara W, Ashley I, Rosner F. Thrombotic thrombocytopenic purpura associated with clopidogrel administration: case report and brief review. Am J Med Sci 2001; 322: 170-2.

4. Scully M. Hunt BJ, Benjamin S et al. Guidelines on the diagnosis and management of thrombotic thrombocytopenic purpura and other thrombotic microangiopathies. Br J Haematol 2012; 158: $323-35$

5. Nayer A, Ortega LM. Catastrophic antiphospholipid syndrome: a clinical review. J Nephropathol 2014: 3: 9-17.

6. Greinacher A, Warkentin TE. Recognition, treatment, and prevention of heparin-induced thrombocytopenia: review and update. Thromb Res 2006 118: $165-76$

7. Warkentin TE, Pai M, Sheppard JI et al. Fondaparinux treatment of acute heparin-induced thrombocytopenia confirmed by the serotonin-release assay: a 30-month, 16-patient case series. J Thromb Haemost 2011; 9: 2389-96.

8. Kadidal VV, Mayo DJ, Horne MK. Heparin-induced thrombocytopenia (HIT) due to heparin flushes: a report of three cases. J Intern Med 1999; 246: $325-9$

9. Muslimani AA, Ricaurte B, Daw HA. Immune heparin-induced thrombocytopenia resulting from preceding exposure to heparin catheter flushes. Am J Hematol 2007: 82: 652-5.

10. Ling E, Warkentin TE. Intraoperative heparin flushes and subsequent acute heparin-induced thrombocytopenia. Anesthesiology 1998; 89 : 1567-9.

11. Warkentin TE. Heparin-induced thrombocytopenia: pathogenesis and management. Br J Haematol 2003; 121: 535-55

12. Pohl C, Harbrecht U, Greinacher A et al. Neurologic complications in immune-mediated heparininduced thrombocytopenia. Neurology 2000; 54: $1240-5$

13. Martel N, Lee J, Wells PS. Risk for heparin-induced thrombocytopenia with unfractionated and low-molecular-weight heparin thromboprophylaxis: a meta-analysis. Blood 2005; 106: 2710-5.
14. Warkentin TE, Sheppard JA, Horsewood P et al. mpact of the patient population on the risk for heparin-induced thrombocytopenia. Blood 2000; 96: $1703-8$

15. Warkentin TE, Heddle NM. Laboratory diagnosis of immune heparin-induced thrombocytopenia. Curr Hematol Rep 2003; 2: 148-57.

16. Keeling D, Davidson S, Watson H. The management of heparin-induced thrombocytopenia. Br J Haematol 2006; 133: 259-69.

17. Bakchoul T, Zöllner H, Greinacher A. Current insights into the laboratory diagnosis of HIT. Int J Lab Hematol 2014; 36: 296-305.

18. Warkentin TE. New approaches to the diagnosis of heparin-induced thrombocytopenia. Chest 2005 127 (suppl): $35 S$ - 45S

19. Lesesve JF, Martin M, Banasiak C et al. Schistocytes in disseminated intravascular coagulation. Int J Lab Hematol 2014; 36: 439-43.

20. Warkentin TE, Kelton JG. Delayed-onset heparininduced thrombocytopenia and thrombosis. Ann Intern Med 2001; 135: 502-6.

21. Goode CJ, Titler M, Rakel B et al. A meta-analysis of effects of heparin flush and saline flush: quality and cost implications. Nurs Res 1991; 40: 324-30.

22. López-Briz E, Ruiz Garcia V, Cabello JB et al. Heparin versus $0.9 \%$ sodium chloride intermittent flushing for prevention of occlusion in central venous catheters in adults. Cochrane Database Syst Rev 2014; 10: CD008462.

23. Hæg A-K, Flaatten KH, Hvingevold SM et al. Sentralt venekateter (SVK) - stell og bruk av tunnelert og ikke-tunnelert kateter hos voksne. www.helsebiblioteket.no/microsite/fagprosedyrer/ fagprosedyrer/svk-cvk-sentralt-venekateter-stellog-bruk-av-tunnelert-og-ikke-tunnelert-kateterhos-voksne (21.8.2015)

Mottatt 10.3. 2015, første revisjon innsendt 9.6. 2015, godkjent 21.8. 2015. Redaktør: Lars Frich 